\title{
Research on Performance-related Pay Problems of Chinese Colleges and Universities under New Situation
}

\author{
Yanming $\mathrm{Li}^{1}$, Deng Pan ${ }^{2}$ \\ ${ }^{1}$ School of Business, Northeast Normal University, Changchun, 130000, China \\ ${ }^{2}$ Personnel Office, Northeast Normal University, Changchun, 130000, China
}

Keywords: colleges and universities; performance-related pay; problem; recommendation

\begin{abstract}
Performance-related pay is an important part of university operation. With the continuous expansion of higher education scale and the comprehensive promotion of "Double First-class" universities construction, the new situation has new requirements for performance-related pay in colleges and universities. Therefore, based on the analysis on the current situation and existing problems about Chinese reform of university teachers' salary system and performance-related pay, this paper further explores the possible reasons for the problems, and draws on the experience of foreign first-rate universities performance-related pay management. In this way, this paper puts forward the policy suggestions which conform to the reform and management of the performance-related pay system in the new period of Chinese, and it provides a new thinking space to promote the rational flow of the outstanding talents in domestic colleges and universities.
\end{abstract}

\section{Introduction}

With the continuous innovation of China's socioeconomic management system, as well as expansion of the enrollment scale and the "Double First-class" universities construction in China, it is gradually becoming diversified and marketed for the development of the income distribution system in Chinese universities. The reform of performance-related pay system in universities has become a hot topic and research since "Income Distribution System Reform Program of Public Institutions Staff" released by the Ministry of Personnel and the Ministry of Finance in 2006. The reform of performance-related pay system in universities is associated not only to the enthusiasm and initiative of the staff, but also to the stable and efficient development of higher education. Therefore, the reform of performance-related pay in universities has been widely concerned by the whole society and has become the key point of the reform of personnel system in universities.

In November 2016, according to the unified deployment of the State Council, universities directly under in the central ministries began to comprehensively implement the reform of the performance-related pay system, which marked the opening of the new round of reform of the income distribution system in Chinese universities. In January 2017, the General Office of the Ministry of Education issued a document about further requiring all subordinate universities to insist on the correct guidance and promote the rational and orderly flow of high-level talents in universities. Under this new background, government has also raised the "Double First-Class" universities construction to the national strategic level. Therefore, on the basis of national policy guidance, it raises a problem for how to construct the performance-related pay system adapted to the "Double First-class" universities construction, which attracts universities' wide attention and must be solved imperatively.

\section{Present Situation}

After decades of reform and innovation, the performance-related pay system in Chinese universities has made some progress. So far, it has moved towards a new stage. In 2010 and 2015, "Outline of the National Medium-to-Long Term Education Reform and Development Plan (2010-2020)" and "Overall Plan for Promotion of World-class Universities and First-class Discipline 
Construction" were introduced. The documents pointed out that the salary of college teachers should be leveraged according to performance, and moreover, it is requirement to establish and improve the performance evaluation mechanism and performance appraisal management mechanism in order to improve the system of performance-related pay distribution. After the introduction of the policy, many colleges and universities have actively explored the performance-related pay reform, and introduced the enterprise employees performance-related pay model into university teachers' salary system, and gradually formed the performance-related management system with the characteristics of university and in line with the actual development needs.

At the same time, the academia has also given a wide range of attention to the reform of the performance-related pay in universities. Scholars have researched the rationality, orientation and fairness of the performance-related pay management system from many fields and perspectives such as management, economics and other disciplines, and now plentiful and substantial results have been achieved. At present, the performance-related pay system researchers mainly focus on higher schools' reform status, performance definition, advantages and problems, proportion of performance, distribution pattern, implementation difficulties, performance evaluation and management and so on [1].

In the current universities performance-related pay system, there are two parts: basic performance-related pay and rewarding performance-related pay. The basic performance-related pay is relatively stable, which is provided by the provinces according to the unified standard. It embodies the economic development, local price level, otherness between different posts and other factors. It is also the affirmation to teachers' executions of their own duties, which works as a role of barrier. Besides, basic performance-related pay mainly used to pay salaries to teachers and staff who perform their duties seriously employed in various types of posts. According to the specific circumstances of universities, it can be divided into post allowance, workload allowance and other items. The other part is rewarding performance-related pay. This kind of pay method is flexibility and mainly set in the total amount of performance-related pay. Universities autonomously formulate detailed rewarding performance-related pay distribution system, according to the relevant standards and steps to carry out corresponding reward. It is the affirmation to teacher overdone the task of work or making a breakthrough. It mainly shows workload, contribution and performance, and according to the results of performance assessment, the distribution follows the principle of more pay for more work and more pay for excellent work. In specific conditions of university, it can be divided into teaching performance allowance, scientific research performance allowance, management performance allowance and so on.

\section{Problems}

The reform of performance-related pay in universities is a part of income distribution system reform, which is promoted by country to reform public institutions management system, establish the characteristics of public institutions, embody the post performance and standardize the order of income distribution. Whether the reform is successful or not is related to the sound development of our higher education and the effective functional exertion. The implementation of performance management, not only helps to speed up the development of higher education, but also helps to effectively inspire the enthusiasm of the staff of universities. However, because of the many factors that affect the performance-related pay and the constraints of the system, there are some problems in the actual operation leading to weaker effects than expected results. At present, the main problems of the performance-related pay distribution in China's universities are as follows: the performance-related pay assessment mechanism is not sound and perfect, the performance-related pay management is not systematic, and the implementation of the performance-related pay system is difficult.

Performance-related pay assessment mechanism is not sound. In recent years, although universities pay more attention to the work performance of teachers year by year, the performance assessment is only formalistic, and the standard is difficult to be accurate, meticulous and 
comprehensive, which is shown as the main factors that determine the salary of college teachers are education, professional title and seniority. For teachers and managers, different posts and different responsibilities couldn't be measured according to the same performance assessment standard. This is not only unfair, but also is not conducive to enthusiasm of work, and also violates the original intention of performance-related pay system. Therefore, in the performance award allocation, we still could not avoid the problems of equalization, qualification and so on, which causing formalistic and weak incentive effect.

Performance-related pay assessment mechanism is not perfect. At present, the reform of performance-related pay system in Chinese universities is still in the initial stage. The evaluation and assessment standards are relatively simple. The teaching-oriented college teachers and scientific-research-oriented college teachers, even professors and lecturers or teaching assistants are different in their workload, the output of scientific research results and the projects declaration in different departments and disciplines. If the performance appraisal process tends to emphasize too much on the number of published papers and weakens the assessment about teachers' ethics, academic ethics and other important aspects, the assessment will be not objective, scientific and comprehensive. To a certain extent, it will also cause the waste of talent resources and it is very detrimental to introduce and cultivate talent of excellent teachers in universities. Then the main body of the performance appraisal system is relatively simple, most of which are departmental leaders, and the assessment results may be influenced by the personal preferences of the evaluators. Therefore, how to establish the "performance " to ensure the "fair" [2], to scientifically quantify the performance-related pay system for the work of the staff, to truly realize the rational allocation of the labor resources in universities, to exploit to the incentive effect of the performance-related pay system to talents, and to avoid the internal contradictions caused by the nonstandard assessment and formalistic, are still a problem that needs to be further solved in the process of building first-class universities in China.

Performance-related pay is lack of systematic management. Because of the lack of top-level design, most universities that implement the performance-related pay system are independent accounting and management by the internal functional departments according to their respective functions and powers. In addition, most of them have a one-sided reliance on high pay and high treatment to grab talents while setting high-level talents' performance-related pay. The phenomenon of salary treatment and allocation of academic resources determined by "academic title" "talent title" affects the long-term stable service of talents. How to formulate a high-level talents salary system scientifically, guide and standardize the rational flow of high-level talents and eliminate the disordered competition of talents, which will be the key problem to be solved in the new round construction of performance-related system.

Implementation of the performance-related pay system is difficult. For the specific plan of performance-related pay reform in universities, it is closely related to the work of the executive department and the whole universities from the detailed formulating process to implementation. In the current situation, how to measure the performance of teaching--oriented teachers and scientific-research-oriented teachers in specific formulation and implementation? How to measure the performance of teachers in popular and general discipline? How to measure the work performance of teachers with high professional titles and academic degree with low one? How to measure the performance of workers in management posts and service posts? These have become the core issues of performance-related pay. If these specific details cannot take into account the interests of all people and cannot achieved pay according to work, it will also has a negative impact on the implementation of the performance-related pay plan.

\section{Recommendations}

The implementation of performance-related pay distribution system not only has the strategic significance of promoting the development of higher education, but also has the realistic significance to stimulate the internal motivation of universities, which must be continuously promoted. On the 
basis of current situation and existing problems analysis in China's universities performance-related pay reform and combining with the present situation of the salary system of China's university teachers, we can get multiple enlightenments. Universities should pay more attention to the reform of performance-related and focus on the construction of a sound and scientific performance-related pay management system, so as to promote the scientific, formalized and standardized management of the performance-related pay in China's universities to make the higher education in China reach a higher level. In this way, it will not only have a positive effect on the rational construction of the "Double First-class" university teachers' compensation and welfare system, but also can better promote the rational flow of excellent teachers.

First of all, universities should follow the national education strategy and the overall development goal of the university, formalize the management system and standards of the performance-related pay, and formulate the performance-related pay system that meets the characteristics of the education industry and requirements of administrative department. Meanwhile, the universities performance-related pay management system must constantly improve the performance evaluation mechanism and reform the performance-related pay by enhancing scientific and public confidence and other ways. Though highlighting the performance orientation, strengthening the top level design to shift down the management center, perfecting the supporting policies, enforce distribution discipline and monitoring by multi-channel to eliminate the illegal issue, the performance-related pay management system can effectively stimulate the internal motivation of universities.

Secondly, the level of performance-related pay of high-level talents should be kept in a reasonable proportion with the average teacher's performance level. High level talent is one of the core competencies of universities. It plays an important role in the construction of disciplines, the quality of personnel training and the promotion of comprehensive ranking. In the formulation of high level talent performance-related pay assessment system, we should insist on the combination of incentive and constraint, spiritual and material encouragement, and conforming to the requirements of post duties in income distribution principle [3] ,which keeps a certain gap between the high level talents and the common teachers' performance welfare. In this way, it not only encourages teachers to improve their teaching and scientific research ability to a higher level, but also make the performance management coordinated and sustainable develop. At the same time, the construction of the performance-related pay system universities should comprehensively take into account the balanced relations among teachers, managers, other technical personnel and workers. "ERG" theory, proposed by Clayton Alderfer, enlightens us that we should design the different schemes of performance incentive according to the different preferences of different people when we establish the performance-related pay system. Different people have different needs and different values, and we need to choose incentive ways and tactics flexibly [4]. Therefore, the performance reward should meet the principle of fully ensuring the optimizing construction of the teaching team and giving priority to the frontline teachers. It should not only reflect the "wood bucket principle" of the performance incentive, but also balance the salary relationship between various kinds of personnel and avoid the phenomenon of "the disparity between the rich and the poor" inside universities. Only when we maximum the function of the performance-related pay to all kinds of personnel, which means arrange the right personnel on the right position and make the best use of them and fully encourage their enthusiasm for work, we can create a campus atmosphere of highlights pay with optimal performance and harmonious development.

Finally, universities should establish and improve the self-discipline system of performance-related pay management system. Apart from improving the management level and formulating a performance-related pay system suitable for development needs in universities, the successful implementation of performance-related pay needs to make full use of the professional organization, carry out the research on the trend of talent flow and rely on professional research institutions, such as the salary branch and the teachers branch, to do investigation, data collection and analysis, and policy guidance. In addition, it is suggested that the famous universities take the lead and set up a salary university alliance on the basis of self-discipline, openness and equality, which could form a community having complementary advantages, mutual cooperation and resource flow. 
In this university alliance, all participant universities seek for common rules and formulate industry standards and norms adapted to the "Double First-class" China's universities development. The University alliance should also play the necessary role of supervision and establish a unified information platform to make the high-level personnel flow information open and transparent, so as to eliminate the disordered flow of high-level talents and the universities injustice competitive behavior by high salary poaching. With this method, universities will realize the sustainable, healthy, orderly and reasonable high-level talents flow, and it will ensure deepening the comprehensive reform of universities and orderly and coordinated development of "Double First-class" construction.

\section{Acknowledgement}

This research is supported by "the Fundamental Research Funds for the Central Universities (2412017QD036)”.

\section{References}

[1] Yu Wensheng. A Review on the Study of Performance-related Pay Reform in Colleges in China [J]. Journal of Sichuan University of Science \& Engineering (Social Sciences Edition), 2012, 27(1): 7-11.

[2] Yuan Benfang, He Xianglin. Reflections on Equity of Performance- Based Pay in Colleges and Universities:Based on a Comparative Analysis of the Campus Allowance System within the Five “211” Ministry- Run Universities [J]. Education \& Economy, 2011(2): 49-53.

[3] Ma Jun, Shan Mingfeng. The Inverted "U- shape" Performance Pay Pattern in Research- Oriented Universities: The Impact and Optimization of Hierarchical Pay Structure [J]. Journal of Shanghai University (Social Sciences), 2013, 30(1): 111-124.

[4] Chen Leyi, Zhou Jincheng. The Development of Merit Pay System in Institutions of Higher Education and its Inspiration for China [J]. Studies in Foreign Education, 2010, 37(8): 91-96. 